\title{
Opowieści pielgrzyma jako wprowadzenie w duchowość hezychastyczną
}

\author{
Irena Saszko \\ Chmielnicki Uniwersytet Narodowy, Ukraina \\ ORCID: 0000-0003-2077-257X \\ irenasaszko@gmail.com
}

I. Saszko, The Way of a Pilgrim as an introduction into the hesychastic spirituality, Elpis, 23 2021: 9-17.

\begin{abstract}
The Way of a Pilgrim was written by an unknown author originated from the second half of the 19th century. This work, which has been very popular in the Orthodox world, is an introduction to the Eastern Christian hesychastic spirituality. This book is a story about the pilgrimage of a Russian peasant to various sanctuaries and monasteries in the Russian Empire. The pilgrim, with the help of his elder - the spiritual father, explores the secret of the unceasing prayer. He draws God's wisdom from the Holy Scriptures and the Philokalia. When the pilgrim meets various people on his way, he talks to them about prayer and shares with them his own experience of God's prayer. The article carried out an analysis of the main issues of the Way of a Pilgrim, namely: the introduction into the Jesus prayer, the transforming power of the Word of God, the fight against passions, and the importance of spiritual guidance in the life of every Christian.

Streszczenie: Opowieści pielgrzyma zostały napisane przez nieznanego autora z drugiej połowy XIX wieku. To cieszące się dużą popularnością w świecie prawosławnym dzieło jest wprowadzeniem we wschodnio-chrześcijańską duchowość hezychastyczną. Książka opowiada o pielgrzymowaniu rosyjskiego chłopa do różnych sanktuariów i monasterów na terenach Imperium Rosyjskiego. Pątnik, przy pomocy swojego starca - ojca duchowego, zgłębia tajemnicę nieustannej modlitwy. Mądrość Bożą czerpie z Pisma Świętego oraz Filokalii. Spotykając na swej drodze pielgrzymowania różne osoby, rozmawia z nimi o modlitwie, a także dzieli się własnym doświadczeniem obecności Boga. W artykule zostały przeanalizowane główne zagadnienia Opowieści pielgrzyma, a mianowicie: wprowadzenie w modlitwę Jezusową, przemieniająca moc Bożego Słowa, walka z pożądliwościami oraz znaczenie przewodnictwa duchowego w życiu każdego chrześcijanina.
\end{abstract}

Keywords: hesychasm, the unceasing prayer, compunction, the Philokalia, the spiritual father

Slowa kluczowe: hezychazm, nieustanna modlitwa, głęboka skrucha, Filokalia, ojciec duchowy

\section{(9) (2)}

Nie ma jednoznacznej odpowiedzi na pytanie, czym jest duchowość chrześcijańska, gdyż jest to rzeczywistość misteryjna, przekraczająca granice racjonalnego myślenia. Łaciński czasownik spirare znaczy tyle, co „oddychać”, zaś pokrewny mu przymiotnik spiritualis oznacza „związany z oddychaniem lub powietrzem". Słowa te maja odniesienie do życia, bowiem życie biologiczne jest nierozerwalnie związane z procesem oddychania. Co więcej, kiedy w II oraz III w. naszej ery przekładano z języka greckiego na łacinę księgi Nowego Testamentu, kluczowe w listach św. Pawła słowo pneumatikos tłumaczono jako spiritualis. W Pierwszym Liście do Koryntian Apostoł Narodów wyjaśnia, że nie mówi „uczonymi słowami ludzkiej mądrości, lecz pouczony przez Ducha, przekładając duchowe (gr. pneumatika) sprawy tym, którzy są z Ducha" (1Kor 2,13). Osoby duchowe to ludzie otwarci na Ducha Bożego, Jego natchnienia i działania. W opozycji do nich są ludzie, których życie polega na egocentrycznym dążeniu do zaspokajania własnych pożądliwości (gr. pathi). Takich ludzi św. Paweł nazywa ludźmi cielesnymi (gr. sarkinos) lub zmysłowymi (gr. psychikos) (por. 2Kor 10,2) (Wiseman 2009, s. 18). W tym kontekście należy podkreślić, że w chrześcijaństwie wschodnim pojęcie duchowości utożsamiane jest z życiem duchowym, rozumianym jako działanie mocy
Ducha Świętego w wierzących, w wyniku czego jednoczą się oni z całą Trójcą Przenajświętszych Osób i otrzymują dar życia nadprzyrodzonego (Leśniewski, 2002, s. 701).

O ile chrześcijański Zachód zna wiele różnych szkół duchowości, które w większym lub mniejszym stopniu powiązane są z charyzmatycznymi osobami (np. św. Benedyktem z Nursji, św. Franciszkiem z Asyżu, sw. Dominikiem Gonzalezem, św. Janem od Krzyża czy św. Teresą Wielką, jak również św. Ignacym z Loyoli, św. Janem Bosko, Jean'em-Jacques'em Olierem oraz innymi), to na chrześcijańskim Wschodzie, zaczynając od III wieku, rozwinął się tylko jeden nurt duchowości, zwany hezychazmem (gr. hesychia - wyciszenie wewnętrzne) (Yep, 2009, s. 304-305; za: Rabiej, 1993, s. 831). Jest to ascetyczne nauczanie o drodze zjednoczenia (gr. koinonia) osoby ludzkiej z Trójjedynym Bogiem poprzez oczyszczenie jej $\mathrm{z}$ różnego rodzaju pożądliwości (gr. pathi) na poziomie ducha, duszy i ciała. W osiągnięciu jedności z Bogiem pomocna jest głęboka skrucha (gr. katanyksis), a także praktykowanie nieustannej modlitwy, połączonej z uwagą (gr. prosoche) i czujnością (gr. nepsis) umysłu (gr. nous) (Аверинцев, 2005, s. 234-235). Na drodze wewnętrznej przemiany człowieka niezbędna jest pomoc ojca duchowego, zwanego inaczej starcem (gr. geron). Starcy to osoby 
prowadzące głębokie życie duchowe, które po wielu latach zmagań duchowych i życia modlitewnego, będąc przynaglone przez Ducha Bożego, podjęły się wyzwania przewodnictwa duchowego zarówno dla mnichów, jak i dla ludzi świeckich. Cechuje ich głęboka miłość do Boga oraz całego stworzenia, a także wrażliwość na sprawy ludzkich cierpień i potrzeb (Leśniewski, 2002, s. 706-707).

W Kościele Wschodnim wyróżnia się trzy okresy rozwoju duchowości hezychastycznej. Pierwszy okres to okres synajski, związany z monasterem św. Katarzyny na Górze Synaj, a także z osobą św. Jana Klimaka († 649), drugi okres to okres athonicki (Święta Góra Athos), a okres trzeci, to tzw. okres słowiański, zwany inaczej neohezychazmem. Okres słowiański naznaczony był wpływem polemiki, toczącej się pomiędzy eremitą - św. Nilem Sorskim († 1508) a archimandrytą - św. Józefem z Wołokołamska $(\dagger 1515)$ na temat tradycji ubóstwa monastycznego, jak też konieczności zachowania reguł życia cenobitycznego św. Bazylego Wielkiego oraz św. Teodora Studyty. Największy rozwój hezychazmu na terenach, zamieszkałych przez Wschodnich Słowian, przypada na wiek XIX. Jest to również okres rozkwitu instytucji starców. Za jego najsłynniejszych przedstawicieli powszechnie uważa się św. Serafina z Sarowa († 1833), a także mnichów z Pustelni Optyńskiej - starca Leonida († 1841), starca Makarego († 1860), starca Ambrożego († 1881) oraz starca Anatola († 1894) (Rabiej, 1993, s. 832; por. Cieślik, 2005, s. 77-17). Warto zauważyć, że na ożywienie duchowości hezychastycznej na Rusi ogromny wpływ wywarł zredagowany poprzez Nikodema Hagiorytę († 1809), a przethumaczony i spopularyzowany w Rosji przez uczniów św. Paisjusza Wieliczkowskiego ( $†$ 1794), zbiór tekstów ascetyczno-mistycznych, składający się z dzieł 38. autorów, żyjących w wiekach IV-XIV, pt. Filokalia ton hieron neptikon, a także powstała w drugiej połowie XIX w. w Rosji książka nieznanego autora pt. Otkrowiennyje rasskazy strannika duchownomu swojemu Otcu, znana w Polsce jako Opowieści pielgrzyma (Drączkowski, Modzelewska, 1989, s. 231).

Wyjątkowość Opowieści pielgrzyma polega na tym, iż stanowi proste wprowadzenie $\mathrm{w}$ duchowość hezychastyczną. Książka ta przeznaczona była przede wszystkim dla osób świeckich, w odróżnieniu od typowych traktatów ascetycznych, które były pisane dla środowisk monastycznych. Główny bohater, a zarazem narrator Opowieści pielgrzyma, pogłębia swoje życie duchowe, wędrując poprzez XIX-wieczne Imperium Rosyjskie - od bezkresnej Syberii, aż po tereny współczesnej Ukrainy (Ненарокова, 2005, s. 292). „Pielgrzym, którego cały majątek stanowi worek sucharów, czotki, Biblia i Filokalia, spotyka na swej drodze wielu ludzi z różnych stanów - chłopów, duchownych, mnichów, kupców i szlachetnie urodzonych. Każde takie spotkanie z tymi ludźmi ubogaca nie tylko pielgrzyma, ale i tych, których spotyka" (Cyrulski, 2011, s. 10). Pielgrzymka więc staje się dla pokornego i ubogiego wędrowcy bardzo dynamiczną, a zarazem wymagającą szkołą życia duchowego, w której, wsłuchując się w Słowo Boże i zgłębiając dzieła Ojców Kościoła, uczy się panowania nad swymi pożądliwościami, a przez to zdobywa bezcen- ny dar ustawicznej modlitwy serca. Swoje doświadczenie posłuszny pątnik opisuje swojemu ojcu duchownemu.

\section{Dążenie do ustawicznej modlitwy jako powołanie każdego chrześcijanina}

Słowa o konieczności nieustannej modlitwy w życiu chrześcijanina, skierowane przez św. Pawła Apostoła do Kościoła w Tesalonikach (por. 1Tes 5,17), można uważać za punkt wyjścia, sedno, a także ostateczny cel duchowości hezychastycznej (Ware, 2003, s. 113). Wszak ustawiczna modlitwa oznacza jednocześnie nieustanne pamiętanie o Bogu, przebywanie w Jego obecności, głęboką zażyłość z Nim. Z tego też względu zachęta św. Pawła do praktykowania nieustannej modlitwy stała się głównym motywem siedmiu opowieści pielgrzyma. Zainspirowany nauczaniem św. Pawła o tym, iż modlitwa chrześcijanina ma być nieustanna (por. 1Tes 5,17), a także zanoszona do Boga w każdej sposobności (por. Ef 6,18) i w każdym miejscu (por. Tm 2,8), pobożny tułacz, nazywający siebie „wielkim grzesznikiem", wyrusza w drogę, a raczej - jak sam o sobie pisze - „biegnie” - aby znaleźć mistrza duchowego i nauczyć się od niego ustawicznego trwania w Bogu (Opowieści, 2011, s. 15-16). W trakcie żmudnych poszukiwań odpowiedzi na zasadnicze pytanie: „Jak modlić się nieustannie, według słów Pieśni nad Pieśniami: 'Ja śpię, ale serce moje czuwa' (PnP 5,2)?”, pielgrzym odkrywa, iż ustawiczna modlitwa jest związana ze zmaganiem duchowym (gr. atlos, cs. podwig), a zarazem twórczym współdziałaniem (gr. synergeia) osoby ludzkiej z Niestworzoną Energią Bożego Ducha. Wymaga też właściwego nastawienia ze strony człowieka, bowiem „ma być zanoszona z czystą myślą i sercem, z płomienną gorliwością, w stałym skupieniu, $\mathrm{z}$ trwożną pobożnością i najgłębszą pokorą" (Opowieści, 2011, s. 174).

Niestety ani pobożny ziemianin, ani gorliwy igumen, których pielgrzym odwiedził na początku swej wędrówki, nie potrafili wyjaśnić mu, w jaki sposób należy modlić się nieustannie. Jedynie pokutujący pustelnik uzmysłowił pielgrzymowi, iż duchy ciemności „najbardziej nienawidzą modlitwy serca", dlatego zawsze toczą okrutną walkę z tymi, którzy pragną nieustannie trwać w Bożej obecności (Opowieści, 2011, s. 24). Nawet jeśli ,próżnymi myślami i grzesznymi zamysłami wróg nie zdoła odciągnąć [modlącego się] od modlitwy, której nie może znieść, to wzbudza w jego pamięci wspomnienia lub podsuwa mu piękne myśli”, a także zwraca go „ku radosnej rozmowie z samym sobą lub stworzeniem" (Opowieści, 2011, s. 79). Pustelnik wyjaśnił wędrowcy, że ze wszystkich, nawet najbardziej szlachetnych czynów, jakich tylko może dokonać człowiek, najważniejszą pozostaje być modlitwa, bowiem bez niej „,nie można odnaleźć drogi do Pana, dociec prawdy, ukrzyżować ciała z namiętnościami i żądzami, rozświetlić serca Chrystusowym światłem i zbawczo zjednoczyć się z Nim" (Opowieści, 2011, s. 20). Przy tym mądry 
starzec nauczył pielgrzyma zasad modlitwy Jezusowej, zalecając, aby ten przy pomocy sznureczka z węzełkami (ros. czotki), kontrolując swe myśli (gr. logismoi), z uwagą (gr. prosoche) i czujnością (gr. nepsis), trzy tysiące razy dziennie powtarzał wezwanie: „Panie Jezu Chryste, Synu Boży, zmiłuj się nade mną!’, z czasem zwiększając liczbę do sześciu, a następnie do dwunastu tysięcy w ciągu dnia, aż modlitwa nie stanie się dla niego ,oddechem i biciem serca" (Opowieści, 2011, s. 26, 172). Zdaniem starca w odmawianiu modlitwy Jezusowej ważne jest nie tylko wewnętrzne nastawienie modlącego się, lecz również postawa zewnętrzna (Opowieści, 2011, s. 23-28). Z tego powodu podał pielgrzymowi dokładną instrukcję modlitwy, a mianowicie, aby „usiadł w milczeniu i odosobnieniu, pochylił głowę, zamknął oczy, oddychał spokojnie, wyobraźnią spoglądał wewnątrz serca, uwolnił umysł, tzn. przeniósł myśli z głowy do serca. Przy oddychaniu zaś cicho ustami lub tylko w myśli powtarzał modlitwę Jezusową" (Opowieści, 2011, s. 22-23). Pierwsza część tej formuły modlitewnej ,zawiera w sobie całą Ewangelię”, tzn. „wprowadza umysł (gr. nous, ros. um) w dzieje życia Jezusa Chrystusa”, a druga jej część „,przedstawia historię naszej niemocy i grzeszności”, liczącej wyłącznie na bezgraniczne Boże miłosierdzie (Opowieści, 2011, s. 143). Modlitwa Jezusowa jest najlepszym sposobem osiągnięcia pełnej koncentracji na Bogu. ,Dowodem tego są przykłady, które ukazują, że ci, którzy byli obarczeni obowiązkami, rozpraszającymi zajęciami, troskami, kłopotami i pracą, nie tylko zawsze wzywali Boskiego Imienia Jezusa Chrystusa, ale właśnie dzięki temu nauczyli się i osiągnęli nieustanną wewnętrzną modlitwę serca" (Opowieści, 2011, s. 181-182).

Początkowo taka intensywna reguła modlitewna stanowiła dla pielgrzyma dużą trudność, gdyż wymagała cierpliwości i samodyscypliny, z czasem jednak zaczął on odczuwać z jej powodu głęboką wewnętrzną słodycz. Praktykowana modlitwa stała się radością jego serca. Doświadczenie nieustannego przebywania w Duchu Świętym uzmysłowiło wędrowcy, iż jedynie gorąca modlitwa, zanoszona do Boga, potrafi uwolnić od lęku, zrodzić w sercu wiarę w Boga oraz zaufanie do Niego, a także wzbudzić pragnienie pełnienia dobrych uczynków (Opowieści, 2011, s. 131, 173, 174). Tęsknota za coraz większą komunią (gr. koinonia) z Bogiem przynaglała go do jeszcze żarliwszego wypowiadania Imienia „Jezus”, którego światłość, poprzez serce pielgrzyma, oświecała wszystkich tych, których spotykał na swojej drodze (Bułgakow (1992), s. 164). Pielgrzym stopniowo odkrywał, iż ,nie wystarczy modlitwę posiadać, należy stać się modlitwą - modlitwą wcieloną. Nie wystarczy wyznaczyć czas na modlitwę: każdy czyn, każdy gest, nawet uśmiech powinien stać się hymnem uwielbienia, ofiarą, modlitwą" (Evdokimov (1962), s. 83). Nawet spotykane podczas pielgrzymki osoby, w pewien sposób stawały się dla pielgrzyma potwierdzeniem tego, że ,świat nie potrzebuje ludzi, którzy mniej lub bardziej regularnie odmawiają modlitwy, ale ludzi, którzy są 'modlitwą" (Behr-Sigel (2018) s. 186). Wszak zarówno jej autorem, jak i mistrzem jest Duch Święty, który „wstawia się za nami przez niewyrażalne błagania" (Rz 8,26) (Opowieści, 2011, s. 145).

„Idę nieraz siedemdziesiąt i więcej wiorst dziennie i nie czuję, że idę - czuję tylko, że odmawiam modlitwę. Kiedy przeszyje mnie srogi mróz, to zacznę z większym natężeniem odmawiać modlitwę i zaraz cały się rozgrzewam. Jeśli zaczyna opanować mnie głód, z jeszcze większym natężeniem przyzywam Imienia Jezusa Chrystusa i zapomnę, że chciało mi się jeść. Kiedy przyplącze się choroba, zacznie się łamanie w plecach i w nogach, zaczynam skupiać się na modlitwie i nie czuję bólu. Kiedy ktoś mi ubliży, tylko przypomnę sobie, jak rozkoszną jest Jezusowa modlitwa - od razu przechodzi obraza i gniew, i o wszystkim zapominam. Stałem się taki, jakbym postradał rozum, niczym się nie przejmuję, nic mnie nie interesuje, na nic na próżno się nie oglądam, i byłbym sam w tej mojej samotności, tylko z przyzwyczajenia chcę jednej rzeczy bezustannie odmawiać modlitwę, bo kiedy zajmuję się nią, odczuwam wielką radość" (Opowieści, 2011, s. 29).

Ten długi cytat przekonuje o tym, iż doświadczenie wolności wewnętrznej jest największym owocem nieustannej modlitwy, bowiem pogrążony w codziennych kłopotach, jak również we własnych występkach i grzechach, człowiek zapomina, iż został obdarzony przez Boga darem wolności zdolnej do urzeczywistnienia prawdziwego życia w miłości - do Boga, drugiego człowieka, a nawet całego kosmosu (Yannaras (1984), s. 26; por. Leśniewski 2008), s. 333-348). Zarówno cały wewnętrzny świat osoby ludzkiej, jak też piękno natury wprowadzało pątnika w stan głębokiego zachwytu. Wszystko skłaniało go do dziękczynienia Bogu: ludzie, drzewa, rośliny, zwierzęta. Wszystko było dla niego rodziną, we wszystkim znajdował przedziwne odbicie jaśniejącego miłością Oblicza Chrystusa (Opowieści, 2011, s. 103). Przemierzając rozległe tereny XIX-wiecznego Imperium Rosyjskiego, zatopiony w modlitwie pątnik, na nowo odkrywał w sobie dar wolności, który jednocześnie stawał się dla niego wyzwaniem i twórczym zadaniem. Odczuwanie nie tylko duchowego, lecz także fizjologicznego ciepła w sercu, będącego skutkiem żarliwej modlitwy, przekonywało go o tym, iż jest bezgranicznie kochany przez Boga, a przez to może we wolności dziecka Bożego hojnie dzielić się tą miłością z innymi ludźmi, a nawet z tymi, którzy czynią mu źle. Ten bowiem, „kto osiągnął prawdziwą modlitwę i miłość, ten nie rozróżnia sprawiedliwego od grzesznego, ale wszystkich jednakowo kocha i nie osądza" (Opowieści, 2011, s. 96). Nieustanna modlitwa jest gwarancją osiągnięcia pokoju serca, tak upragnionego przez każdego człowieka (Opowieści, 2011, s. 147).

„Od tego czasu zacząłem odczuwać różne regularne doznania w sercu i w umyśle. Niekiedy bywało, że coś rozkosznie wrzało w sercu, taka była w nim lekkość, wolność i uciecha, że cały się zmieniałem i byłem zatopiony w zachwycie. Niekiedy czułem płomień miłości do Jezusa Chrystusa i do wszelkiego stworzenia. Kiedy indziej sam z siebie wylewałem słodkie łzy dziękczynienia Panu, który umiłował mnie, potępionego grzesznika. Niekiedy moje wcześniejsze głupie rozumowanie tak się rozjaśniało, że 
łatwo pojmowałem i rozmyślałem o tym, o czym wcześniej nie mogłem nawet pomyśleć. Czasem słodkie ciepło z serca rozlewało się po całym moim ciele i z rozrzewnieniem czułem przy sobie wszędzie Bożą wszechobecność. Zdarzało się, że odczuwałem wewnątrz siebie wielką radość z przyzywania do Imienia Jezusa Chrystusa i doświadczałem, co znaczą wypowiedziane słowa: 'Królestwo Boże jest w was' (Łk 17,21)” (Opowieści, 2011, s. 49-50, 101).

Trwanie w nieustannej relacji z Bogiem napełniało trudne, bowiem przepełnione goryczą, ubóstwem i samotnością, życie pielgrzyma głębokim sensem. Był pełen zdumienia dla misterium osoby ludzkiej - jej ducha, duszy i ciała. Zdumiewał się tym, w jaki sposób jego serce, rozpalone przez Ducha Świętego, potrafi płonąć miłością do Boga podczas pracy, odpoczynku, czytania książek, rozmów z innymi ludźmi, a nawet snu (Opowieści, 2011, s. 51, 103). Co więcej, im głębiej pielgrzym zanurzał się w modlitwę, tym lepiej zaczynał rozumieć niezgłębione tajemnice Bożej mądrości, zawarte w Słowie Bożym oraz w pismach Ojców Kościoła. Pojmowanie prawd wiary dla nieuczonego chłopa przychodziło w sposób naturalny, odruchowo wywołując w jego wnętrzu kontemplacyjny podziw dla Boga oraz modlitwę uwielbienia (Opowieści, 2011, s. 64, 68, 89). Jednym z dowodów na to może być m.in. dyskusja pielgrzyma z Polakiem wyznania rzymskokatolickiego na temat Filokalii. Taktownie i z wielką kulturą duchową pielgrzym wyjaśniał katolikowi wartość i znaczenie traktatów ascetycznych Ojców filokalicznych, podkreślając, iż są to Ojcowie wspólnej wiary. Szukając zatem tego, co łączy, a nie tego, co dzieli, główny bohater Opowieści pielgrzyma wykazuje się głębokim zrozumieniem arcykapłańskiej modlitwy Chrystusa, w której żarliwie modli się On do Ojca o dar jedności dla wszystkich braci i sióstr (por. J 17,1-26) (Opowieści, 2011, s. 64-66). Modlitwa, nieustannie zanoszona do Boga, wyciszyła serce pielgrzyma w taki sposób, aby był zdolny usłyszeć nie tylko Boga, przemawiającego w jego wnętrzu, ale także innych ludzi, nierzadko mających odmienne zdanie. W skromnym i nieuczonym pątniku spełniły się słowa Ewagriusza z Pontu o tym, że prawdziwym teologiem jest tylko ten, kto prowadzi głębokie życie modlitewne. Wszak, ,ci, którzy umieją kochać, o Bogu wiedzą najwięcej. I to właśnie do nich mają przysłuchiwać się teologowie" (Бальтазар (2015), s. 13). Opowieści pielgrzyma są przykładem tego, jak wnikliwe czytanie Pisma Świętego może zaprowadzić osobę ludzką na wyżyny życia duchowego.

\section{Uzdrawiająca i uwalniająca moc Bożego Słowa}

Już od pierwszych stron Opowieści pielgrzyma możemy zauważyć, iż to właśnie Pismo Święte zainspirowało prostego rosyjskiego chłopa do pogłębienia swojego życia duchowego. Paradoksalnie bowiem Słowo Boże nie tyle odpowiadało na nurtujące go pytania, ile raczej stawiało mu istotne pytania, dotyczące relacji z Bogiem, a także sensu życia i przemijania (Opowieści, 2011, s. 15; Werbiń- ski (2013), s. 52-54). W taki sposób, rodzące się w nim pytania egzystencjalne przyczyniły się do bardzo dynamicznego rozwoju duchowego pielgrzyma. Czytanie Świętej Księgi zarówno rozgrzewało jego serce, jak i pogłębiało w nim duchowy głód Boga i Jego obecności.

Warto podkreślić, iż to właśnie Słowo Boże uzdrowiło rany serca pielgrzyma, doświadczone przez niego w dzieciństwie, a także zadane mu w latach młodzieńczych. Gdy miał trzy lata, zmarli jego rodzice. Wychowujący go dziadek od wczesnego dzieciństwa rozmiłował chłopca w czytaniu Świętej Księgi. Nawet przed śmiercią staruszek zapowiedział, wówczas już ożenionemu pielgrzymowi, aby codziennie czytał na głos Pismo Święte. Pozostał wierny temu poleceniu wraz ze swoją małżonką, która niejednokrotnie płakała na dźwięk słów życia wiecznego (Opowieści, 2011, s. 71-73). Rozczulało ją bowiem to, że „w Biblii wszystko jest tak doskonale opisane" (Opowieści, 2011, s. 73). Ponadto już od najmłodszych lat wiele przykrości doświadczał pielgrzym od swojego starszego brata, który z powodu zazdrości najpierw go okaleczył, a potem poprzez chciwość i pragnienie zemsty, spalił cały jego majątek. Z pożaru ocalała jedynie Biblia, z którą od tamtego czasu pielgrzym już nigdy się nie rozstawał (Opowieści, 2011, s. 71-73). Słowo Boże uwolniło go również ze stanu depresji po śmierci żony i stało się bodźcem do tego, aby pozostawiwszy dawne, choć spokojne i w miarę stabilne życie, wyruszył w niekończącą się pielgrzymkę (Opowieści, 2011, s. 74). Zażyłość ze Słowem Bożym pomagała pielgrzymowi przezwyciężać różnego rodzaju trudności na szlaku jego wędrowania. Zawsze, kiedy brakowało mu sił, zarówno fizycznych, jak i psychicznych czy duchowych, aby kontynuować pielgrzymkę, sięgał po Pismo Święte, szukając w nim natchnienia, mocy i pocieszenia. Czytanie Biblii wywoływało w nim gorące łzy wzruszenia i wdzięczności wobec Boga za dar Jego Słowa (Opowieści, 2011, s. 35).

W Opowieściach pielgrzyma zostały przedstawione trzy szczególnie ważne historie, opowiadające o znaczeniu Słowa Bożego w życiu chrześcijanina. Pierwsza historia relacjonuje spotkanie pielgrzyma z pewnym kapitanem, nawróconym i uwolnionym $\mathrm{z}$ nałogu alkoholizmu, dzięki intensywnemu czytaniu Ewangelii. Pewnego razu, ów wojskowy, pogrążony w rozpaczy, nie widząc sensu swojego życia, spotkał mnicha, który polecił mu czytanie na głos Ewangelii, a zwłaszcza w tych chwilach, gdy nadchodziła go ochota na picie wina. Pomimo nurtujących go wątpliwości kapitan postanowił skorzystać z rady mnicha. Z czasem zaczął doświadczać uwalniającej mocy Bożego Słowa. Przestał spożywać alkohol, a czytając codziennie jedną Ewangelię, uczynił Słowo Boże stałym pokarmem dla swojej duszy. Nawet gdy na początku nie wiele rozumiał z tego, co czytał, to jednak odczuwał, iż zbawcza moc Dobrej Nowiny obecna jest już w samych słowach Ewangelii (Opowieści, 2011, s. 35-38).

Kolejna historia jest związana z nieustannie czytającym Ewangelię pątnikiem, który przystał do narratora Opowieści pielgrzyma w Poczajowie. Od spotkania w Ławrze Poczajowskiej dwóch pielgrzymów, przemierzając tereny 
ówczesnej Ukrainy, dialogowało o Ewangelii, „uczącej życia chrześcijańskiego, zawartego w modlitwie". Rozmiłowany w Słowie Bożym wędrowiec wyjaśniał pielgrzymowi główne zasady słuchania Ewangelii, z którego przecież rodzi się wiara (por. Rz 8) i bez którego „nie można nauczyć się właściwej modlitwy”. „Siądź w samotnej celi i czytaj, i wciąż od nowa czytaj Ewangelię!" - zalecał pielgrzymowi anonimowy współtowarzysz podróży. Mówił również o owocach duchowych z czytania Dziejów oraz Listów Apostolskich. W tych bowiem księgach Nowego Testamentu zawarte są nie tylko konkretne wskazówki odnoszące się do modlitwy, ale również są przedstawione dary i charyzmaty Ducha Świętego (Opowieści, 2011, s. 155-161).

W trzeciej historii jest mowa o profesorze, prowadzącym bezbożne i rozpustne życie. Powodem jego nawrócenia stała się przyjaźń z rzekomym paryżaninem, który udawał, że jest wysokich lotów intelektualistą, a w rzeczywistości okazał się demonem, pragnącym ostatecznie zwieść profesora $z$ drogi zbawienia. Cała prawda wyszła na jaw w chwili, gdy profesor podał mu do ręki księgę Ewangelii, znajdującą się pomiędzy książkami w jego gabinecie. Wówczas zły duch "zatrząsł się i zniknął" (Opowieści, 2011, s. 165). Z przerażenia profesor stracił przytomność, a gdy ocknął się, to w całym ciele odczuł paraliż. Został w cudowny sposób uzdrowiony, dzięki nieustannemu słuchaniu ,słodkiego głosu życia wiecznego, ukazanemu w Słowie Bożym” (Opowieści, 2011, s. 166). Z powyższych historii wynika, iż Ewangelia posiada uwalniającą i uzdrawiającą moc. Proklamacja Bożego Słowa nie tylko uwalnia osobę ludzką od destrukcyjnych wpływów demonów, leczy ją na duchu, duszy i ciele, lecz również egzorcyzmuje przestrzeń, w której się znajduje (Opowieści, 2011, s. 37). Zakorzenienie w Bożym Słowie oczyszcza serce człowieka, a także otwiera je na przyjęcie Radosnej Światłości Bożego Ducha.

Natomiast „kluczem, otwierającym tajemnicę Pisma Świętego" nazywa pielgrzym Filokalię - księgę, którą, na polecenie swojego ojca duchowego, nabył jeszcze na samym początku swojej wędrówki (Opowieści, 2011, s. 4122). Po tę lekturę, oprócz Biblii, sięga pielgrzym podczas całego swojego wędrowania. Znajduje w niej bowiem wyjaśnienie tego, co w Piśmie Świętym stanowi dla niego trudność i jest niezrozumiałe. Dzięki Filokalii odkrywa, „kim jest wewnętrzny ukryty człowiek serca, czym jest prawdziwa modlitwa, czym jest uwielbianie w Duchu, czym królestwo wewnątrz nas, czym jest niewyrażalne wstawiennictwo Ducha Świętego, [...] zaślubiny ducha, a także westchnienie serca 'Abba, Ojcze!' (Rz 8,15-16)" (Opowieści, 2011, s. 41). W Filokalii znajduje również „pełną i kompletną naukę o tym, jak osiągnąć duchową Jezusową modlitwę w umyśle i sercu”, a także ,posmakować słodkich jej owoców" (Opowieści, 2011, s. 112). Czytanie Filokalii nie pozwalało pielgrzymowi zatrzymać się w duchowym rozwoju, ulec ospałości, małoduszności czy lenistwu duchowemu (Opowieści, 2011, s. 129). Przeciwnie, lektura owej księgi wzbudzała w nim pragnienie Boga oraz życia zgodnie z Ewangelią. Uczył się z niej zasad prowa- dzenia walki z pożądliwościami (gr. pathi), aby w czystości serca, móc rozkoszować się łaską prawdziwej hezychii.

\section{Walka $\mathrm{z}$ pożądliwościami (gr. pathi) oraz głęboka skrucha (gr. katanyksis)}

Wnikliwe czytanie zarówno Filokalii, jak i Drabiny Raju św. Jana Klimaka przekonuje, że powszechne przeświadczenie o tym, iż duchowość hezychastyczna polega wyłącznie na praktykowaniu modlitwy Jezusowej, jest błędne. Z pewnością, duchowość hezychastyczna jest duchowością ustawicznego trwania w Bogu, chodzenia w Duchu Świętym i doświadczania Jego Niestworzonej Światłości. Według Ojca filokalicznego Nikitasa Stethanosa, w zjednoczeniu z Boskim Logosem najbardziej pomaga „czysta noetyczna modlitwa”. Najdoskonalszym zaś sposobem jej osiągnięcia jest modlitwa Jezusowa, charakteryzująca się brakiem rozproszenia oraz pełną koncentracją na Zbawicielu (Leśniewski (2006), s. 236). Jednak sama modlitwa nie wystarczy. W parze $\mathrm{z}$ nią musi iść wytrwała praca nad sobą, walka z grzechem aż do przelania krwi (por. Hbr 12,4). Innymi słowy, niezbędna jest metanoiaradykalna zmiana sposobu myślenia i postępowania człowieka, do której w Ewangelii według św. Marka zaprasza sam Pan Jezus (por. Mk 1,15).

Ze względu na to, iż człowiek jest osobą trychtonomiczną, tzn. duchowo-psycho-somatyczną, na każdą z tych sfer wpływa zarówno Duch Święty, jak i złe duchy. Jeśli Duch Boży oczyszcza osobę ludzką, uświęca ją i oświeca Swoją przebóstwiającą Światłością, to złe duchy zaciemniają jej umysł oraz powodują zaburzenia, inaczej zwane pożądliwościami lub namiętnościami (gr. pathi). Na poziomie ciała są to: obżarstwo (gr. gastrimargia), nieczystość (gr. porneia) i chciwość (gr. filarguria), na poziomie duszy - gniew (gr. orge), smutek (gr. lype), acedia (gr. akedia) oraz na poziomie ducha: próżność (gr. kenodoksja) i pycha (gr. hiperfania). Warto pamiętać, iż „to właśnie ci, którzy żarliwie oddają się modlitwie, w szczególny sposób narażeni są na straszliwe i gwałtowne pokusy" (Opowieści, 2011, s. 60). Aby im się oprzeć, powinni zachowywać wewnętrzną czujność (gr. nepsis), gdyż „diabeł, jak lew ryczacy, krąży, szukając, kogo pożreć” (1P 5,8). Ojcowie filokaliczni nauczają, iż hezychasta powinien nieustannie czuwać, aby przy pomocy słuchania Bożego Słowa, ustawicznego przyzywania słodkiego Imienia Jezus, przed którym zegnie się ,każde kolano istot niebieskich i ziemskich, i podziemnych" (Flp 2,10), a także szeroko rozumianej ascezy natychmiast demaskować zwodnicze strategie kusiciela. Jednakże skutkiem praktyk duchowych wcale nie musi być brak odczuwania żadnych namiętności/pożądliwości (gr. pathi). Jeśli pojawiają się w sferze wyobraźni, to należy dokładać wszelkich starań, aby nie poddać się żadnej z nich (Ware, 2011, s. 142). Ponadto w duchowości hezychastycznej bardzo ważne miejsce zajmuje głęboka skrucha (gr. katanyksis), której towarzyszy wylewanie łez 
- tak wewnętrznych, jak i zewnętrznych. Światłość Ducha Świętego podczas żarliwego przyzywania Imienia Jezus przez hezychastę pomaga mu $\mathrm{w}$ dostrzeganiu aktualnego stanu swego wnętrza. Hezychaści bowiem często targani są przez różnego rodzaju demony. Wyznawanie w szczerości i pokorze grzechów oczyszcza umysł. Warto pamiętać, iż starotestamentowy psalmista wznosił swoją modlitwę do Stwórcy, wołając: „Kto jednak dostrzega swe błędy? Oczyść mnie od tych, które są skryte przede mną. Także od pychy broń swojego sługę, niech nie panuje nade mną" (Ps 19, 13-14). W taki sposób, człowiek, będąc „oczyszczony przez łzy, osłodzony przez głęboką skruchę oraz oświecony przez Światłość Ducha Pocieszyciela", dostępuje łaski zarówno beznamiętności (gr. apatheia), jak i wyciszenia wewnętrznego (gr. hesychia), czyli „aktywnej i twórczej ciszy" (łac. negotiosum silentium) - jak to pięknie ujął św. Ambroży z Mediolanu (Leśniewski (2006), s. 236; za: Ware, 2011, s. 131).

Również narrator Opowieści pielgrzyma głębokiej skrusze (gr. katanyksis) poświęca cały rozdział swojej książki, który niewątpliwie można uznać za traktat na temat sakramentu spowiedzi. Spowiednik, mieszkający w pustelni nieopodal Kijowa, wyjaśnia pielgrzymowi, na czym polega doskonały żal za grzechy. Uświadamia mu, że praktykowanie nieustannej modlitwy, prowadzącej do hezychii, jest niemożliwe bez ustawicznego trwania w prawdzie o sobie, tzn. konfrontacji własnych intencji, pragnień oraz myśli ze Słowem Bożym (Opowieści, 2011, s. 132-134). Skupianie się na zewnętrznych praktykach religijnych, a nawet na własnych wzniosłych uczuciach i poruszeniach serca, może być zwodzeniem, absolutnie zaślepiającym chrześcijanina. Ucząc pielgrzyma warunków dobrej spowiedzi, pustelnik pokornie wyznał, iż sam częstokroć nie zauważał ,strasznych grzechów, które kryły się w nim" (Opowieści, 2011, s. 139):

„Uważnie zwracając mój wzrok na samego siebie i obserwując bieg wewnętrznego mojego życia, poprzez doświadczenie, przekonałem się, że nie kocham Boga, nie żywię miłości do bliźniego, nie wierzę w nic objawionego i jestem przepełniony pychą i pożądliwością. Wszystko to istotnie znajduje w sobie, szczegółowo przypatrując się moim uczuciom i postępkom. [...] Chociaż z zewnątrz okazuję pokorę, ale wszystko to przypisuję swoim siłom i siebie samego uważam za lepszego od innych. [...] Drażnią mnie ci, którzy nie doceniają mnie i uważam, że nie umieją oni oceniać ludzi. [...] Jeśli już dążę do czegoś dobrego, to tylko z tym zamiarem, że otrzymam pochwałę lub, że będę miał duchowe wyrachowanie lub świecką radość. Słowem, bezustannie czynię z siebie własnego bożka, któremu nieprzerwanie służę, szukając we wszystkim rozkosznego uczucia i pokarmu dla zmysłowych moich namiętności i żądz" (Opowieści, 2011, s. 134, 138).

Uzmysłowienie sobie własnej grzeszności wraz z poczuciem wdzięczności wobec Boga zarówno napawa modlącego się prawdziwą radością, jak i czyni go człowiekiem o sercu pokornym i pełnym prostoty. I to właśnie taki człowiek zyskuje Bożą przychylność wraz z darem Jego przebaczenia. Ten fakt potwierdza sam Pan Jezus, gdy opowiada swoim uczniom opowieść o faryzeuszu i celniku (por. Łk 18,9-14).

Jak widać, prowadzenie głębokiego życia duchowego jest nierozłącznie związane z doświadczeniem walki duchowej. Aby w tej walce nie utracić punktów orientacyjnych, a w ciemnościach duchowych - promieni Niezachodzącej Światłości Bożego Ducha, niezbędna jest pomoc mądrego i doświadczonego przewodnika duchowego (Opowieści, 2011, s. 24). Jest on niczym latarnik, oświecający modlitwą wstawienniczą, słowem proroczym oraz gestem dobroci drogę swojego duchowego syna, gdy ten przedziera się przez mroki duchowych poszukiwań. Ponadto, jako serdeczny i wierny przyjaciel, wspiera ucznia dobrą radą, a także chroni przed złudzeniami wyobraźni (gr. fantasia) (Зелинский, 2008, s. 51-60). Gdy zaś demony zadają mu bolesne rany duszy, ojciec duchowy troskliwie je opatruje, a także zalewa oliwą swojej - mimo iż bardzo wymagającej - to jednak zawsze pokornej i łagodnej miłości. Albowiem - jak naucza Pismo - „brat wspomożony przez brata jest mocarzem" (Prz 18,19) (Opowieści, 2011, s. 61).

\section{Znaczenie ojcostwa duchowego}

Cała tradycja Ojców Pustyni oraz Filokalii podkreśla wielkie znaczenie ojca duchowego we wprowadzeniu chrześcijanina $\mathrm{w}$ duchowość hezychastyczną (Misijuk, 2014). Można powiedzieć, iż życie duchowe prowadzone bez pomocy starca (gr. geron), wcześniej lub później skończy się dla początkującego hezychasty przerażającymi atakami demonicznymi, które spowodują jego totalne zagubienie. „Bez nastawienia starca (gr. geron) duchowe działanie okaże się niewłaściwe i mało efektywne" (Opowieści, 2011, s. 23). Nie bez powodu więc anonimowy autor zatytułował historię swojej, przede wszystkim duchowej, wędrówki słowami: „Szczere opowieści pielgrzyma, poświęcone duchownemu ojcu". Z pewnością pragnął przez to uświadomić swoim czytelnikom, jak ważne jest posłuszeństwo wobec starca. „Lekarz bowiem nie wyleczy chorego, o ile ten nie zwróci się do niego z ufnością i błaganiem, i nie pokaże mu swoich ran" (Klimak (2016), s. 340). Relacja ze starcem ma być podobna do relacji Dawida $\mathrm{z}$ Jonatanem, a więc powinna być czuła, ciepła i pełna miłości. Taka relacja jest bardzo wzruszająca, ponieważ cechuje ją szczerość i wierność. Dzięki relacji ze starcem uczeń pobiera naukę zarówno miłości do Chrystusa-Słowa, jak i miłości do samego ojca duchowego, który staje się dla niego „przyjacielem i tłumaczem Słowa” (Вилкен, 2015, s. 261). Podobnie nauczał również św. Jan Klimak, twierdząc, iż „dobrze jest mieć noetycznych przyjaciół, bo nikt nie może dopomóc nam w osiągnięciu cnoty tak bardzo, jak oni” (Klimak, 2016, s. 337). Szczere ujawnianie wszystkich swoich myśli przewodnikowi duchowemu jest gwarancją duchowego wzrostu oraz nieomylności drogi, którą się kroczy. $Z$ tego też względu, wędrowiec rozpoczyna swoje pielgrzymowanie właśnie od poszukiwania mą- 
drego mistrza nieustannej modlitwy oraz znawcy tajemnic życia duchowego.

Dzięki Opowieściom pielgrzyma dowiadujemy się o różnych funkcjach starca, wobec swojego syna duchowego. Przede wszystkim w imieniu Chrystusa udziela on duchowemu synowi swojego ojcowskiego błogosławieństwa, które $\mathrm{z}$ jednej strony jest wyrażeniem jego aprobaty wobec dobrych poczynań syna, $z$ drugiej zaś - oznacza wiarę $\mathrm{w}$ to, że na drodze ku osiągnięciu stanu beznamiętności (gr. apatheia) i nieustannej modlitwy serca uda mu się przezwyciężyć wszelkie zło. Błogosławieństwo starca zapewnia syna o jego ojcowskiej życzliwości i trosce. Wszak w języku Biblii błogosławić oznacza dobrze komuś życzyć oraz dobrze o kimś myśleć i mówić. Ojcowskie błogosławieństwo ma swoje źródło w samym Bogu i właśnie dlatego tryska życiem i hojnością darów (Guillet, 1994, s. 80). Mądry mistrz duchowy delikatnie i bez pośpiechu, dostosowując się do duchowych możliwości i rytmów swojego ucznia, otwiera przed nim tajniki prowadzenia duchowych bitew, jak również uczy żywej i wytrwałej modlitwy. Co więcej, nie narzucając się, lecz z cierpliwością przyjaciela, starzec wprowadza swojego syna duchowego w orbitę swojej osobistej relacji z Bogiem (Opowieści, 2011, s. 2428). Warto zauważyć, iż miłość i troska ojca duchownego towarzyszą uczniowi nawet po śmierci starca (gr. geron), a rzeczy pozostawione po nim, mają dla syna moc relikwii. W Opowieściach pielgrzyma starzec po swojej śmierci regularnie odwiedzał pątnika, zwłaszcza gdy znajdował się on w sytuacjach kryzysowych. Przez sen nauczał swojego duchowego syna prawidłowego czytania Filokalii albo po prostu pozwalał mu duchowo odczuć swoją obecność, która napełniała wnętrze pielgrzyma światłością, a także wzbudzała w nim pragnienie modlitwy (Opowieści, 2011, s. 46-47, 85). Również pewnego razu, dzięki czotkom swojego starca (gr. geron), pielgrzym w cudowny sposób został uratowany od groźnego wilka. Wszak, ,starzec, który posiadał tę koronkę, był święty. [...] Koronka zawsze była w rękach świętego, a więc poprzez stykanie się jej z rękami i poprzez ich ciepło, zaszczepiona została w niej święta siła - siła niewinnego stanu pierwszego człowieka" (Opowieści, 2011, s. 55). Modlitwa starca, zarówno za jego życia, jak i po śmierci, zawsze towarzyszyła pielgrzymowi. Można powiedzieć, iż była największym darem starca dla jego syna duchowego i dlaczego odczuwał on jej moc na drogach swojego pielgrzymowania (Opowieści, 2011, s. 140). Co więcej, z biegiem czasu sam pielgrzym osiągnął mądrość i doświadczenie starca, stając się mimo woli przewodnikiem duchowym dla spotykanych przez siebie ludzi. Można tu mówić o pewnej sukcesji starczestwa - mistrz wychowuje mistrza. W jednej ze swoich opowieści pielgrzym wyznaje, iż ludzie sami zaczęli zbliżać się do niego, ,już nie tylko, aby im poczytał, czy udzielił porad, ale i z różnymi życiowymi troskami, a nawet, by odnalazł ich zguby i straty" (Opowieści, 2011, s. 56-57, 98-99). Pielgrzym doskonale wiedział, iż „ten, kto często uczy innych, pogrąża się w hańbie, cierpi napaść i pokusy za tych, którzy odnieśli dzięki niemu korzyść" (Opowieści, 2011, s. 103). Jednakże, bez względu na różnego rodzaju zagrożenia du- chowe, dla każdego zawsze znajdował czas i każdemu starał się pomóc z ogromną pokorą i wielkodusznością. Jego, choć pełne prostoty, to jednak namaszczone przez Ducha Świętego słowo, uzdrawiało i dodawało otuchy. Było to słowo mocy i miłości, gdyż wyłaniało się z milczącego i rozmodlonego serca. A - jak wiadomo - „bez wewnętrznego uczucia i odczuwania wszelkie wygłoszone słowo będzie bez pożytku" (Opowieści, 2011, s. 107). Pielgrzym w czasie swojej duchowej pielgrzymki, będąc pouczony przez starca, a także przez dzieła Ojców filokalicznych, zrozumiał, iż „nie tylko nam samym przystoi, wedle Bożej zapowiedzi, modlić się nieustannie w imię Chrystusa, ale należy też uczyć i odkrywać tę modlitwę przed innymi, w ogóle przed wszystkimi: mnichami, świeckimi, mądrymi, prostymi, mężami, żonami i dziećmi, i wzbudzać we wszystkich gorliwość do nieustannej modlitwy" (Opowieści, 2011, s. 61).

$$
* * *
$$

We współczesnym świecie - pełnym chaosu i niepokoju, gdzie przyszłość wzbudza raczej lęk niż nadzieję, powrót do duchowości hezychastycznej może okazać się bardzo pomocnym w odzyskaniu równowagi duchowej oraz wewnętrznego ukojenia. Wschodniochrześcijańska duchowość hezychastycza uczy nie tyle zatrzymania się, ile uporządkowania swojego życia - zarówno wewnętrznego, jak i zewnętrznego. Pomaga ona w odkrywaniu i zrozumieniu związku pomiędzy światem duchowym i światem materialnym. Współczesny człowiek bardzo często czuje się osamotniony i bezradny. Głęboko w swym sercu pragnie jednak być z kimś i dla kogoś. Nie jest to przypadkowe, gdyż każda osoba ludzka jest bytem relacyjnym, a wynika to $\mathrm{z}$ faktu stworzenia jej na obraz i podobieństwo Boga w Trójcy Przenajświętszych Osób. Jednak, jeśli człowiek nie doświadcza miłości, to nie potrafi też nią się dzielić, co powoduje, że traci on zdolność wchodzenia $\mathrm{w}$ życzliwe oraz trwałe relacje $\mathrm{z}$ innymi ludźmi. Zagrożeniem staje się świat wirtualny, będący światem różnego rodzaju iluzji wyobrażeniowych. Człowiek poprzez zakorzenienie $\mathrm{w}$ świecie wirtualnym coraz bardziej staje się niewolnikiem własnych pożądliwości (gr. pathi). Przestaje panować nad złymi wyobrażeniowymi myślami i traktuje je jako coś, co jest wpisane w jego naturę. Jego wybory naznaczone są hedonizmem, a błędy, które regularnie popełnia, powodują $\mathrm{W}$ nim poczucie winy oraz pogrążają $\mathrm{w}$ depresję. Aby móc zatem wyrwać się ze stanu duchowego letargu oraz egzystencjalnego zagubienia, potrzebne jest wejście na drogę uzdrawiającego doświadczenia Bożej miłości, w czym również pomocną może okazać się duchowość hezychastyczna. Jest ona bowiem przede wszystkim duchowością terapeutyczną. Skorzystanie z mądrości i doświadczenia duchowego Ojców filokaliczych może pomóc współczesnym ludziom w uzyskaniu pełni zdrowia duchowo-psychiczno-fizycznego (Leśniewski, 2016). Jest to szczególnie potrzebne chrześcijanom, żyjącym w świecie zdominowanym przez konsumpcję i hedonizm, w którym nie praktykuje się szeroko rozumianej ascezy, a więc zarówno postu i pokłonów do ziemi, 
jak i ćwiczeń duchowych. Integralna asceza jest bardzo pomocna w osiągnięciu pokoju serca, uśmierzeniu cierpienia, a także przywróceniu duchowego ładu i harmonii, aby mieć poczucia życia szczęśliwego (Opowieści, 2011, s. 187). Należy podkreślić, iż celem duchowości hezychastycznej nie jest umartwienie ciała, lecz jego uzdrowienie, a co za tym idzie - uduchowienie (Ware, 2011, s. 168; por. Leśniewski, 2008, s. 78-95).

Szczególnie pomocne w rozwoju życia duchowego mogą stać się Opowieści pielgrzyma dla osób świeckich. W książce tej została wskazana „metoda”, dzięki której mogą oni odnaleźć pokój serca nie poprzez „siedzenie w mrocznej celi”, lecz „w dynamicznym ruchu” - na dro- dze, która ma określony początek, lecz nigdy się już nie kończy (Špidlík, 2000, s. 366). Dzieło to zachęca do poszukiwania duchowych autorytetów oraz przypomina o tym, iż współczesny hezychasta powinien praktykować nieustanną modlitwę Jezusową w samotności, a zarazem świadczyć o Bogu w Trójcy Przenajświętszych Osób w czasie każdego spotkania z innymi ludźmi. Każda bowiem osoba ludzka jest powołana do zażyłości z Bogiem, Który Jest Miłością. Choć Opowieści pielgrzyma zostały napisane ponad sto lat temu, to są aktualne i w pełni zrozumiałe dla chrześcijanina żyjącego w XXI wieku. Książka ta budzi głód pragnienia Boga. Zachęca do słuchania Dobrej Nowiny i ustawicznego przyzywania obecności Zbawiciela.

\section{Bibliografia}

Averincev, S. (2005). Isihazm. W: Sofiâ-Logos-Slovar' (s. 234235) Kiev: Duh ì Lìtera [Аверинцев C. (2005). Исихазм. W: София-Логос-Словарь (с. 234-235) Киев: Дух і Літера].

Bal'tazar, G.U. fon. (2015). Varta vìri liše lûbov, (N. Komarova, Perekl.). Kiïv: Duh ì Lìtera 2015 [Бальтазар, Г.У. фон. (201 5). Варта віри лише любов, (Н. Комарова, Перекл.). Київ: Дух і Літера 2015].

Behr-Sigel, E. (2018). Miejsce serca. Wprowadzenie w duchowość prawosławna. (A. Kocot, Tłum.). Kraków: Wydawnictwo Uniwersytetu Jagiellońskiego.

Bułgakow, S. (1992). Prawosławie. Zarys nauki Kościoła prawosławnego. (H. Paprocki, Tłum.). Białystok-Warszawa: Orthdruk-Formica.

Cieślik, I. (2005). Starcy Pustelni Optyńskiej. Kraków: Wydawnictwo Homini.

Cyrulski, M. (2011). Wstęp. W: Opowieści pielgrzyma. Tyniec: Wydawnictwo Benedyktynów.

Drączkowski, F., Modzelewska, B. (1989). Filokalia. W: L. Beńkowski (red.) Encyklopedia Katolicka (t. V, s. 230-231). Lublin: Towarzystwo Naukowe Katolickiego Uniwersytetu Lubelskiego.

Evdokimov, P. (1962). Sacrement de l'Amour: le Mystère conjugal à la lumière de la Tradition orthodoxe. Paris: Editions de 1, Epi.

Guillet, J. (1994). Błogosławieństwo. (K. Romaniuk, Tłum.). W: X. Leon-Dufour (red.), Stownik teologii biblijnej (s. 78-85). Poznań: Pallotinum.

Klimak, Jan (2016). Drabina Raju. (W. Polanowski, Tłum.). Kęty: Wydawnictwo: Marek Derewiecki.

Lesniewski, Ch. (2016). Clés spirituelles pour une plénitude de vie. Thérapie chrétienne au service de l'homme contemporain. (Colette Courtoy, Traduit). Nouan-le-Fuzelier: EdB.

Leśniewski, K. (2002). Prawosławna duchowość. W: M. Chmielewski (red.), Leksykon duchowości katolickiej (s. 701-713). Lublin-Kraków: Wydawnictwo „M”.

Leśniewski, K. (2006). „,Nie potrzebuja lekarza zdrowi...” Hezychastyczna metoda uzdrawiania człowieka. Lublin: Wydawnictwo KUL.

Leśniewski, K. (2008): Opowieści pielgrzyma jako książka o wolności w Bogu. W: S. Pawłowski (red.), Różnić się w zgodzie. Ksiega pamiatkowa dedykowana Księdzu Profesorowi Leonardowi Górce SVD z okazji 40-lecia pracy naukowo-dydaktycznej (s. 333-348). Lublin: Wydawnictwo Katolickiego Uniwersytetu Lubelskiego.

Leśniewski, K.(2008). Duchowość hezychastyczna - wczoraj i dziś. W: (H. Paprocki (red.). Wiara i poznanie: księga pamiatkowa dedykowana jego eminencji profesorowi Sawie (Hrycuniakowi) prawosławnemu metropolicie warszawskiemu i całej Polski. (78-95). Białystok: Wydawnictwo Uniwersytetu w Białymstoku.

Misijuk, W. (2014). Przewodnictwo duchowe $w$ monastycyzmie prawosławnym. Lublin: Prawosławna Diecezja Lubelsko -Chełmska.

Nenarokova, M. (2005). «Otkrovennye rasskazy strannika duhovnomu svoemuotcu»: stilizaciâ $\mathrm{v}$ duhe romantizma W: N. Višnevskaâ, E. Saprykina (red.), Romantizm. Večnoe stranstvie (s. 290-306). Moskva: Nauka [Ненарокова, M. (2005). «Откровенные рассказы странника духовному своему отцу»: стилизация в духе романтизма W: Н. Вишневская, Е. Сапрыкина (red.), Романтизм. Вечное странствие (s. 290-306). Москва: Наука].

Opowieści pielgrzyma (2011). (M. Cyrulski, Tłum). Tyniec: Wydawnictwo Benedyktynów.

Pentkovskij, A. (2010). Kto napisal «Otkrovennye rasskazy strannika». Žurnal Mosovskoj Patriarhii, (1), 55-59 [Пентковский, А. (2010). Кто написал «Откровенные рассказы странника». Журнал Мосовской Патриархии, (1), 55-59].

Pentkovskij, A. (2018). Istoriâ teksta i avtor «Otkrovennyh rasskazov strannika». Bogoslovskie trudy, (47-48), 343-449 [Пентковский, А. (2018). История текста и автор «Откровенных рассказов странника». Богословские Труды, (47-48), 343-449].

Rabiej, S. (1993). Hezychazm. W: J. Walkusz (red.), Encyklopedia Katolicka (t. IV, s. 831-832). Lublin: Towarzystwo Naukowe Katolickiego Uniwersytetu Lubelskiego.

Špidlík, T. (2000). Myśl rosyjska. Inna wizja człowieka. (J. Dembska, Tłum.). Warszawa: Wydawnictwo Księży Marianów.

Uer, K. (2009). Pravoslavna Cerkva. (N. Rogačevs'ka, Pereklad). Kiïv: Duh ì Lìtera [Уер К. (2009). Православна Церква. (Н. Рогачевська, Переклад). Київ: Дух і Літера]. 
Vilken, R. L. (2015). U pošukah obliččâ Božogo. Vvedennâ u bogoslov'â rann'oï Cerkvi. (T. Timo, Perekl.). L'vìv: Vidavnictvo Ukraïns'kogo katolic'kogo unìversitetu [Вилкен, Р. Л. (2015). У пошуках обличчя Божого. Введення у богослов'я ранньої Церкви. (Т. Тимо, Перекл.). Львів: Видавництво Українського католицького університету].

Ware, K. (2003). Módlcie się nieustannie: ideał ustawicznej modlitwy we wschodnim monastycyzmie (W. Misijuk, Tłum.). W: K. Leśniewski, W. Misijuk (red.), Królestwo wnętrza. (s. 113-129). Lublin: Prawosławna Diecezja Lubelsko-Chełmska.

Ware, K. (2011). Milczenie w modlitwie: znaczenie hezychii (W. Misijuk, Tłum.). W: K. Leśniewski, W. Misijuk (red.), Tam skarb twój, gdzie serce twoje... (s. 125-149). Lublin: Prawosławna Diecezja Lubelsko-Chełmska.

Werbiński, I. (2013). Duchowa droga chrześcijanina odczytana w publikacji Opowieści pielgrzyma. Studia Wrocławskie, (15), s. 49-60.

Wiseman, J. A. (2009). Historia duchowości chrześcijańskiej. (A. Wojtasik, Tłum.). Kraków: Wydawnictwo WAM.

Yannaras, Ch. (1984). The Freedom of Morality. (E. Briere, Transl.). Crestwood NT.

Zelinskij, V. (2008). Družba kak duhovničestvo W: K. Sigov (red.), Družba: ee formy, ispytaniâ i dary. Uspenskie čteniâ (s. 51-60). Kiïv: Duh ì Lìtera 2008 [Зелинский, В. (2008). Дружба как духовничество W: К. Сигов (ред.), Дружба: ее формы, испытания и дары. Успенские чтения (с. 5160). Київ: Дух і Літера].

Rozmiar artykułu: 1,2 arkusza wydawniczego 